\title{
Prvé dokumentované hniezdenie orliaka morského (Haliaeetus albicilla) v Turci a na Liptove
}

\author{
The first documented breeding of the White-tailed Sea-eagle \\ (Haliaeetus albicilla) in the Turiec and Liptov regions (N Slovakia)
}

\section{Peter VRLÍK ${ }^{1}$ \& Martin Dobrota ${ }^{2}$}

\author{
${ }^{1}$ Správa TANAP, Hodžova 11, SK-03101 Liptovský Mikuláš, Slovakia; e-mail: petervrlik@gmail.com \\ ${ }^{2}$ Slobody 23, 03901 Turčianske Teplice, Slovakia; e-mail: mdobrota73@gmail.com
}

\begin{abstract}
This article deals with the first documented and successful breeding of White-tailed Sea-eagle (Haliaeetus albicilla) in Turiec and Liptov regions in northern Slovakia. In the Turiec Basin, two different breeding attempts were observed in 2020 and 2021. The two nests of the one pair were located on different trees of the Scots pine (Pinus sylvestris) and in total four eaglets fledged. In the Liptov Basin, one pair bred successfully on a European larch (Larix decidua) in 2021, and brought up one eaglet. All these breeding attempts were successful thanks to regular monitoring of localities, strengthening of unstable nests, guarding against man-induced disturbance and possible tree felling, and by declaration of a protection zone.
\end{abstract}

Key words: White-tailed Sea-eagle, breeding, population increase, Slovakia

Orliak morský (Haliaeetus albicilla) je rozšírený v Európe a Ázii, od Islandu až po východnú Sibír a Japonsko. Na juhu areálu hniezdi v Európe po Chorvátsko a v Ázii po Kaspické more. Hniezdi tiež v Grónsku (Orta et al. 2016, Schepers 2020). Najpočetnejšie populácie sú v Nórsku, Rusku, Pol'sku a Nemecku. Na Slovensku bolo jeho hniezdenie známe v povodí Dunaja - prvý údaj je z r. 1931 (Hudec \& Černý 1977), hniezdil tam do roku 1964 (Štollmann, 1966). V rokoch 1960 - 1961 bolo zistené neúspešné hniezdenie 1 páru na Oravskej priehrade (Kocian 1960). Odvtedy nebolo na našom území vyše viac ako 30 rokov zaznamenané žiadne hniezdenie. Až v roku 1998 je potvrdený nález obsadeného hniezda $\mathrm{v}$ povodí Dunaja (Trnka et al. 1998, Chavko 2002, Bohuš 2011 ). Následne sa v d'alších rokoch našli nové hniezdne lokality na Podunajsku (Bohuš et al. 2009), od roku 2004 pri rieke Morava (Danko
2005) a v roku 2004 prvý a v roku 2006 druhý pár na východnom Slovensku (Danko 2005, Lipták \& Mihók 2007). Na severe Slovenska pri Oravskej priehrade opätovne zahniezdili orliaky v roku 2010 (Suchánek 2011). V roku 2013 bol počet orliakov na Slovensku odhadnutý na 15 párov (Chavko 2014), v r. 2017 na 30 párov (Št’astný \& Krištín 2021). Náš príspevok opisuje historicky prvé úspešné hniezdenia orliakov morských v Turci a na Liptove.

Hniezdenie v Turci

Orliaky morské v Turci pozorujeme už od konca 90-tych rokov minulého storočia, pričom najviac údajov pochádza zo severnej a južnej časti kotliny (leg. M. Dobrota, M. Apfelová, R. Ret'kovský, P. Kubik, T. Flajs a iní in verb.): z obdobia rokov 1999 až 2019 máme informácie o 160 záznamov o výskyte orliaka z Turca, najmä z okolia Turčianskych Teplíc a vodnej 
nádrže Krpel’any, vrátane preletov nad dolinami okolitých pohorí. V posledných štyroch rokoch sa početnost' pozorovaní zvýšila $(n=96)$ a je možné, že ku zahniezdeniu došlo už v roku 2019. Prvé doložené hniezdenie týchto dravcov v Turci sa nám podarilo preukázat' 15. 4. 2020 (leg. M. Dobrota). Hniezdna lokalita sa nachádza v južnej časti Turčianskej kotliny v nadmorskej výške $553 \mathrm{~m}$ v rovinatom lesnom komplexe tvorenom prevažne smrekovými a borovicovými porastmi vo veku približne 80 až 100 rokov. Najbližšia ,väčšia“" vodná plocha (5 ha rybník) sa nachádza asi $2 \mathrm{~km}$ od hniezdiska. Hniezdo bolo vybudované na borovici lesnej (Pinus sylvestris), vo výške cca 25 metrov, takmer pod jej vrcholom. Hniezdny strom sa nachádzal na okraji rozsiahlej rúbane a bol teda vystavený náporu najmä severných vetrov. Samotné hniezdo bolo postavené pomerne labilne a hniezdny materiál bol ukladaný vel'mi riedko, takže počas hniezdenia sa hniezdo začalo pomaly rozpadat'. Hniezdny pár tvorili adultné orliaky, ktoré boli označené ornitologickými krúžkami. Hniezdo bolo dohl'adané v polovici apríla, ešte počas inkubácie znášky. Hniezdo bolo často z dial'ky kontrolované, najmä po období vetra a búrok, aby sa zistilo, či nedošlo k jeho zrúteniu. V spolupráci s miestnymi lesníkmi bolo dohodnuté, že sa počas hniezdenia v blízkosti hniezda nebude vykonávat' rušivá hospodárska činnost'. Dve mlád'atá boli v hniezde pozorované 9. 5.2020 a obidve boli 4. 6. 2020 označené ornitologický- mi a odčítacími krúžkami (leg. M. Macek; obr. 1a). Zároveň bolo vykonané spevnenie hniezda tak, aby vydržalo aspoň do vyletenia mlád'at. Podl'a spätného výpočtu inkubácia začala okolo 18. 3. 2020. Zvyšky potravy na hniezde boli identifikované ako ratica $\mathrm{z}$ jelienčat'a (Cervus elaphus) a perie z myšiaka hôrneho (Buteo buteo). Juvenil bol pozorovaný pri hniezde ešte 10. 7. 2020. Hniezdo sa na konci hniezdenia vplyvom nepriaznivého počasia úplne rozpadlo, avšak obidve mlád'atá úspešne vyleteli začiatkom júla 2020 a v okolí lokality boli následne pozorované aj v d'alších mesiacoch.

V roku 2021 orliaky postavili stabilné hniezdo opät' na borovici, cca 4,1 km od minuloročného hniezda, v nadmorskej výške $536 \mathrm{~m}$. Hniezdo bolo dohl'adané 23. 2. 2021, v období tvorby jeho výstelky. Inkubácia začala 18. 3. 2021, liahnutie mlád'at prebiehalo 25. 4. 2021 (zaznamenaná potrava na hniezde) a 3. 5. 2021 ich prvé priame pozorovanie v hniezde. Opät' dve mlád'atá boli krúžkované 5. 6. 2021 (leg. M. Macek). Nájdená potrava pozostávala len zo zvyškov kože, pravdepodobne Cervidae alebo Suidae. Už lietajúce mladé jedince boli pozorované na hniezde 15. 7. 2021 a ich prílety na hniezdisko ešte 3. 8. 2021.

Za predpokladu zabezpečenia efektívnej ochrany lokality pred vyrušovaním by tu orliaky mohli úspešne hniezdit' aj v nasledujúcich rokoch.
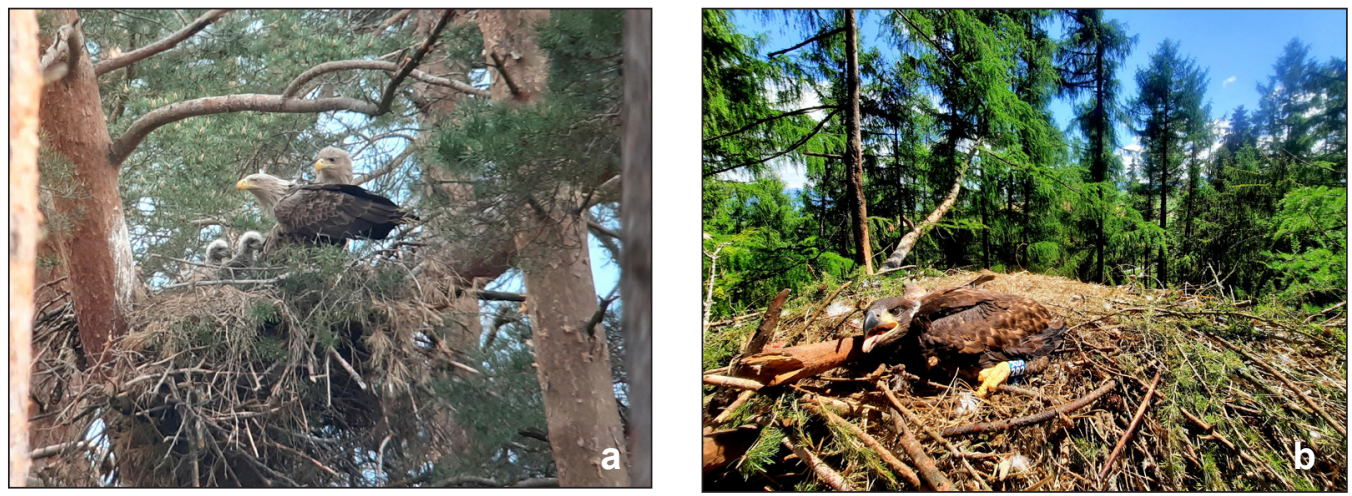

Obr. 1. Pár orliakov morských s mlád’atami, Turiec, 18. 5. 2021 (a; foto: M. Dobrota). Prvé liptovské mlád’a orliaka pri krúžkovaní, 2. 6. 2021 (b; foto: J. Korňan).

Fig. 1. Pair of White-tailed Sea-eagle with nestlings, Turiec Region, May 18, 2021 (a; photo by M. Dobrota). The first nestling of White-tailed Sea-eagle from Liptov Region just ringed, June 2, 2021 (b; photo by J. Korňan). 


\section{Hniezdenie na Liptove}

Prvé pozorovania orliakov morských pochádzajú z Liptova z okolia priehrady Liptovská Mara z konca 70-tych rokov minulého storočia (Karč 1987). Až do roku 2019 však išlo o pozorovania zo zimného obdobia a tieto jedince s príchodom jari koncom februára a $\mathrm{v}$ marci sa $\mathrm{z}$ okolia priehrady vytratili (vlastné pozorovania). Orliaky sme sa snažili viac rokov $\mathrm{k}$ hniezdeniu motivovat' výstavbou hniezdnych podložiek, ale doteraz žiadnu neobsadili. V roku 2014 sa v oblasti zdržoval jeden adultný orliak, hniezdne správanie však nebolo pozorované (leg. J. Kicko, P. Vrlík). Prelom nastal v roku 2019, kedy sa od konca apríla začal v okolí priehrady Liptovská Mara zdržiavat' dospelý samec tvoriaci pár s mladou samicou (leg. P. Vrlík). Po dlhom a náročnom monitoringu sa 6. 3. 2021 podarilo lokalizovat' zálet orliaka s hniezdnym materiálom do lesného porastu. Následne bolo dohl'adané hniezdo na smrekovci opadavom (Larix decidua) vo výške cca 20 metrov nad zemou. Lokalita sa nachádza v Liptovskej kotline, v nadmorskej výške $640 \mathrm{~m}$. Asi $5 \mathrm{~km}$ od hniezdiska, na l'ade priehrady, bolo 9. 3. 2021 prvýkrát pozorované párenie orliakov, neskôr aj v blízkosti hniezda. Inkubácia znášky začala pravdepodobne 19. 3. 2021. V tomto čase pristúpili pracovníci Správy TANAP-u aj k fyzickému stráženiu lokality s ciel'om predchádzat' vyrušovaniu hniezdiaceho páru. Pozorovaním hniezda z dial'ky bola 24. 4. 2021 zistená zmena v správaní samice, ktorá sa skláňala k hniezdnej kotlinke, zrejme kŕmila, dá sa predpokladat', že v tento deň sa vyliahlo mlád'a. Pri krúžkovaní neskôr sa zistilo, že sa vyliahlo len jedno mlád'a. Súvisí to asi aj s mladým vekom samice, čo je možné dokladovat' hnedo sfarbenými koncami chvostových pier (dospelé vtáky majú chvostové perá na konci čisto biele). Pri krúžkovaní dňa 2. 6. 2021 bol ako potrava nájdený na hniezde pleskáč vysoký (Abramis brama). Mladý orliak bol označený modrým odčítacím krúžkom (leg. J. Korňan; obr. 1b). Úspešne vyletel v druhej dekáde júla (leg. J. Mikuš). Orliaky morské boli viackrát pozorované pri kleptoparazitickom odoberaní potravy (rýb) iným druhom vtákov, napríklad čajkám bielohlavým (Larus cachin- nans), potápačom vel'kým (Mergus merganser), kormoránom vel'kým (Phalacrocorax carbo). Naopak, najmä v okolí hniezda boli orliaky dost' často napádané blízko hniezdiacimi krkavcami vel'kými (Corvus corax), orlami krikl'avými (Clanga pomarina), myšiakmi hôrnymi (Buteo buteo), alebo prelietajúcimi čajkami bielohlavými (L. cachinnans).

Ochrana hniezdiska bola na podnet Správy TANAP-u zabezpečená rozhodnutím Okresného úradu životného prostredia v Liptovskom Mikuláši.

Aj vd'aka ochranárskym aktivitám populácia orliakov morských v strednej Európe narastá. Počet párov v Pol'sku, Mad'arsku, Česku aj Rakúsku sa zvyšuje (Schepers 2020). Tento pozitívny trend sa odzrkadl'uje aj na Slovensku, kde postupne $\mathrm{z}$ dvoch párov hniezdiacich $\mathrm{v}$ r. 1998, stúpol odhadovaný počet hniezdiacich párov do r. 2013 na 15, v 2017 na 30 párov (Št'astný \& Krištín 2021) a v 2021 na 40 - 45 párov (Chavko in verb.). Väčšina hniezdísk je monitorovaná pracovníkmi Štátnej ochrany prírody, členmi Ochrany dravcov na Slovensku alebo dobrovol'níkmi. Žial' ešte stále dochádza aj k nezákonnému odstrelu a tráveniu dravcov, orliakov nevynímajúc (Deutschová 2018). Preto je vel'mi dôležité málopočetnú slovenskú populáciu pozorne sledovat'. Všetky tri opísané hniezdenia v Turci a na Liptove boli úspešné, pretože sme strážením a d'alšími opatreniami na lokalitách zabezpečili potrebný pokoj.

\section{Pod'akovanie}

Za pomoc pri monitoringu d'akujeme M. Macekovi, R. Ret'kovskému, J. Kickovi, J. Topercerovi, J. Mikušovi, J. Korňanovi, J. Zuskinovi. Za monitoring a stavbu umelých hniezd vd'aka J. Hol'movi, P. Majkovi, E. Feriancovej, J. Čendulovi. Za pripomienky k rukopisu d'akujeme M. Peigerovi a dvom recenzentom, za úpravy a literatúru J. Kickovi. Za anglický preklad L. Lončíkovi.

\section{Literatúra}

BoHUš M. 2011: Sčítanie zimujúcich orliakov morských na slovenskom úseku Dunaja v zimách 2008/2009 až 2010/2011. - Tichodroma 23: 53-56.

Bohuš M., Lengyel J. \& RÁc P. 2009: The White-tailed 
Eagle (Haliaeetus albicilla) in Slovakia. — Denisia 27: 79-83.

DANKo Š. 2005: Vzostup hniezdnej populácie orliaka morského (Haliaeetus albicilla) v strednej Európe: Prvý záznam hniezdenia na východnom Slovensku. — Tichodroma 17: 63-67.

Deutschová L. 2018: Varovanie: Obete otráv toxickými látkami pribúdajú - dávajte si pozor! — https://www. dravce.sk/web/index.php/sk/aktuality-2018/1423-varovanie-obete-otrav-toxickymi-latkami-pribudajudavajte-si-pozor. Navštívené 17. 1. 2022.

Chavko J. 2002: Orliak morský. —- Pp.: 172-174. In: DaNKo Š., DARoloví A. \& KrišTín A. (eds.): Rozšírenie vtákov na Slovensku. Veda, Bratislava.

Chavko J. 2014: Status populácie orliaka morského (Haliaeetus albicilla) na Slovensku. — In: KovÁŘovÁ J. (ed.): Sborník př́íspěvků z konference na téma „Umíme žít s orly? Aneb jak se daří orlům v Česku a na Slovensku“. Zoologická zahrada Ostrava, Ostrava.

Hudec K. \& ČERnÝ W. (eds.) 1977: Fauna ČSSR Ptáci Aves, díl II. - Academia, Praha.

KARČ P. 1987: Príspevok k poznaniu kvantity a kvality vodného vtáctva priehrady Liptovská Mara a vodnej nádrže Bešeňová. - Vlastivedný zborník Liptov 9: 9-60.

Kocian A. 1960: Prvé zahniezdenie orliaka morského (Haliaeetus albicilla L.) pri Oravskej priehrade. -
Biológia 15: 933.

LiptÁк J. \& MıнóK J. 2007: Proof of nesting by a second pair of White-tailed Sea Eagles (Haliaeetus albicilla) in Eastern Slovakia. Slovak Raptor Journal 1: 43-44.

Orta J., Kirwan G. M., Christie D. A., Boesman P. F. D. \& MARKs J. S. 2016: White-tailed Sea-eagle (Haliaeetus albicilla). - Pp.: 122. In: DEl Hoyo J., Elliott A., Sargatal J. \& Christie D. A. (eds.): Handbook of the Birds of the World Alive. Lynx Edicions, Barcelona. Schepers F. 2020: Haliaeetus albicilla. White-tailed Eagle. - Pp.: 472-473. In: Keller V., Herrando S., Voříšek P., Franch M., Kipson M., Milanesi P., Martí D., Anton M., Klvañová A., Kalyakin M. V., Bauer H.-G. \& Foppen R. P. B. (eds.): European Breeding Bird Atlas 2: Distribution, Abundance and Change. - European Bird Census Council \& Lynx Edicions, Barcelona.

SuchÁNeK O. 2011: Hniezdenie orliaka morského (Haliaeetus albicilla) po 50-tich rokoch pri Oravskej priehrade. - Vtáky 6(1): 4-5.

Štollmann A. 1966. Ako d'alej s ochranou orliakov morských na Dunaji? — Ochrana př́rody 21: 116-118.

Trnka R., Trnka A. \& BoHUš M. 1998: Výskyt, početnost', monitoring a ochrana orliaka morského (Haliaeetus albicilla) na Slovensku v rokoch 1996-1997. — Ochrana prírody 16: 177-191. 